\author{
Dr. sc. Maša Marochini Zrinski ${ }^{1}$ \\ Pravni fakultet Sveučilišta u Rijeci
}

\title{
IZAZOVI U PRIMJENI I TUMAČENJU KONVENCIJE U REPUBLICI HRVATSKOJ
}

\author{
UDK: 342.7(4) \\ Primljeno: 15. 12. 2017. \\ Izvorni znanstveni rad
}

\begin{abstract}
Europska konvencija za zaštitu ljudskih prava i temeljnih sloboda, kao najvažniji paneuropski ugovor za zaštitu ljudskih prava te Europski sud za ljudska prava, kao tijelo zaduženo za nadzor nad primjenom Konvencije, danas imaju veliki značaj u Republici Hrvatskoj prije svega svojim utjecajem na rad hrvatskih sudova i ostalih nadležnih tijela. U ovom radu će biti prikazane presude i odluke Suda protiv Republike Hrvatske koje su, prema mišljenju autorice, značajne za hrvatski pravni poredak, neke jer su potaknule legislativne promjene, neke jer su bile pokretač promjena u ponašanju nadležnih hrvatskih tijela, a neke jer su izazvale kontroverze među hrvatskom javnosti prvenstveno zbog načina na koji Europski sud primjenjuje i tumači Europsku konvenciju. Iz potonjeg razloga u radu su prikazane i metode tumačenja koje Europski sud koristi u svom radu, kao i problemi koji nastaju korištenjem navedenih metoda tumačenja, s obzirom na to da se praksa Europskog suda i način na koji Sud tumači Konvenciju uvelike razlikuju od pozitivističke primjene prava karakteristične za Republiku Hrvatsku.
\end{abstract}

Ključne riječi: Europska konvencija za zaštitu ljudskih prava, Europski sud za ljudska prava, tumačenje Konvencije, presude i odluke protiv Republike Hrvatske

\section{UVOD}

Europska konvencija za zaštitu ljudskih prava i temeljnih sloboda (dalje u tekstu: Konvencija, Europska konvencija) ${ }^{2}$ stupila je na snagu u Republici Hrvatskoj (dalje u tekstu: RH) 5. studenog 1997., nakon ratifikacije i prihvaćanja u Hrvatskom saboru. Prvo vrijeme nakon stupanja na snagu nije naišla na veliki odjek u hrvatskoj javnosti, ${ }^{3}$ no već početkom 2000 . godine počela se javljati svijest građana (i dakako njihovih zastupnika) o mogućnosti zaštite temeljnih ljudskih prava pred Europskim

1 Dr. sc. Maša Marochini Zrinski, docent, Katedra: Teorija prava i države, ljudska prava, filozofija prava i javna politika, Department for Theory of Law and State, Human Rights, Philosophy of Law and Public Policy, Institucija: Pravni fakultet Sveučilišta u Rijeci, Hahlić 6, 51000 Rijeka, Faculty of Law, University of Rijeka, email adresa: mmarochini@pravri.hr, br. tel.: 051359533.

2 (Europska) Konvencija za zaštitu ljudskih prava i temeljnih sloboda, pročišćeni tekst, MU 18/97, 6/99, 14/02, 13/03, 9/05, 1/06, 2/10.

3 Iako je već prvi dopušteni zahtjev protiv RH podnesen 1998. u predmetu Truhli protiv Hrvatske, zahtjev br. 45424/99, od 28. VI. 2001. 
sudom za ljudska prava (dalje u tekstu Sud, Europski sud). U tekstu koji slijedi bit će prikazane pojedine presude Suda protiv Republike Hrvatske, značajne za hrvatski pravni poredak. Razloge za njihov značaj možemo naći u legislativnim promjenama koje su potaknule, te u promjenama u ponašanju nadležnih hrvatskih tijela koje su pokrenule. Nadalje, neke od prikazanih presuda i odluka izazvale su kontroverze među hrvatskom javnosti prvenstveno zbog načina na koji Europski sud primjenjuje i tumači Europsku konvenciju. Upravo je zadnji navedeni razlog i motiv za pisanje ovog rada.

\section{UKRATKO O EUROPSKOJ KONVENCIJI I NJENOJ PRIMJENI}

Konvencija u svom originalnom tekstu sadrži trinaest suštinskih prava, ne računajući članak 1. koji sadrži opću obvezu država o poštovanju ljudskih prava kao i obvezu država osigurati svakoj osobi pod svojom jurisdikcijom prava i slobode zajamčene Konvencijom. Do danas je prošla kroz mnoge izmjene putem Protokola (nikada izvorni tekst Konvencije nije mijenjan), kako onih koji proširuju katalog zajamčenih prava za čije stupanje na snagu nije potrebna ratifikacija svih država ugovornica, tako i onih koji mijenjaju nadzorni sustav nad primjenom Konvencije (za čije je stupanje na snagu potrebna ratifikacija svih država potpisnica Konvencije). Tako je do danas uz Konvenciju doneseno šesnaest protokola, od čega je 14 na snazi, dok su Protokoli 15. i 16. otvoreni za potpisivanje. ${ }^{4}$ Prava zajamčena Konvencijom temeljna su građanska i politička prava, dok su Protokolima dodavana građanska i politička, ali i prava koja imaju određene ekonomsko-socijalne aspekte (poput prava na mirno uživanje vlasništva i prava na obrazovanje). Svakako je Konvencija jedan od najvažnijih dokumenata za zaštitu ljudskih prava, no njen značaj prije svega proizlazi iz rada Europskog suda za ljudska prava.

Europski sud ustanovljen je 1959. u kojem trenutku se pojedinci nisu mogli neposredno obraćati Sudu, već isključivo putem Europske komisije za ljudska prava (dalje u tekstu: Komisija). Ključne promjene u nadzornom sustavu nad primjenom Konvencije nastupile su 1998. stupanjem na snagu Protokola 11., ukidanjem Komisije i ustanovljenjem novog, stalnog Suda. Također, od stupanja na snagu Protokola 11. pojedinci imaju pravo izravnog obraćanja Sudu, a sve države dužne su prihvatiti nadležnost Suda za odlučivanje u sporovima. Sljedeća velika promjena

4 Protokolom br. 15. predviđaju se sljedeće značajne izmjene: načelo supsidijariteta i doktrine o slobodnoj procjeni unesene su u preambulu Konvencije; skraćuje se rok za podnošenje zahtjeva sa šest na četiri mjeseca; izmijenjena je gornja dobna granica kandidata za suca Europskog suda; te donosi određene izmjene u pogledu kriterija značajne štete. Protokolom br. 16. uvodi se savjetodavna funkcija Europskog suda u svezi s tumačenjem i interpretacijom Konvencije i sudske prakse. Republika je Hrvatska u srpnju 2016. potpisala Protokol 15. uz još 44 države članice Vijeća Europe, a isti će, s obzirom na karakter izmjena, stupiti na snagu kada ga ratificiraju sve države članice (u listopadu 2017. je ratificiran od strane 35 država članica). Protokol 16. je potpisan od strane 10 država članica, a ratificiran od strane 8 . Republika Hrvatska u listopadu 2017. još nije niti potpisala, niti ratificirala navedeni Protokol. Isti će stupiti na snagu kada ga ratificira 10 država članica. http://www.echr.coe.int/pages/home.aspx?p=basictexts. 
u nadzornom sustavu nastupila je 2010. stupanjem na snagu Protokola $14 .{ }^{5}$ Cilj donošenja ovog protokola bio je prije svega olakšati filtriranje nedopuštenih predmeta uvođenjem instituta suca pojedinca kao i smanjiti opterećenje Vijeća od 7 sudaca prenošenjem dijela nadležnosti na Odbore od 3 suca.

Kada govorimo u uvjetima dopuštenosti za podnošenje zahtjeva Sudu, oni su zapravo vrlo jasni i određeni, te propisani čl. 34. i 35. Konvencije. Usprkos tome, upravo je najveći broj zahtjeva podnesen Europskom sudu nedopušten jer ne udovoljava jednom od propisanih uvjeta. Valja spomenuti i problem koji se javljao vezan uz zahtjeve proglašene nedopuštenim od suca pojedinca a koji je to mogao učiniti bez davanja ikakvog obrazloženja. No, od lipnja 2017., umjesto pisma kojim ih se obavještava da je njihov zahtjev proglašen nedopuštenim, podnositelji zahtjeva zaprimit će odluku suca pojedinca u kojoj ce isti navesti na kojim je osnovama i iz kojih razloga zahtjev odbačen kao nedopušten. Ono što ostaje jest nemogućnost ulaganja žalbe kao i brisanje predmeta s liste zahtjeva nakon donošenja ove odluke. Ova promjena potaknuta je zahtjevima država ugovornica, kao i pravnicima koji se bave zaštitom ljudskih prava. ${ }^{6}$

U odnosu na Republiku Hrvatsku, Sud je u 2016. godini ispitao 678 zahtjeva, od čega je čak 639 proglašeno nedopuštenim. ${ }^{7}$ Dakle, Sud je odlučivao o povredama konvencijskih prava u svega 34 predmeta te je u čak 25 predmeta pronašao povredu nekog prava iz Konvencije. Gledajući ovu statistiku, proizlaze dva zaključka. Prvo, velika većina zahtjeva protiv RH odbacuje se jer ne udovoljavaju procesnim pretpostavkama te drugo, kada zahtjev udovolji uvjetima dopuštenosti, u većini će predmeta Sud naći povredu konvencijskog prava od strane Republike Hrvatske. ${ }^{8}$ Unatoč ovoj statistici, od stupanja na snagu Konvencije u Republici Hrvatskoj do danas, primjetne su velike promjene, i to u samoj suštini predmeta koji se pojavljuju pred Sudom kao i u ponašanju i stavu nacionalnih tijela, kako sudova tako i ostalih nadležnih tijela, a sukladno presudama Suda, što će biti prikazano u nastavku.

5 Protokol 14. je otvoren za potpisivanje 2004., no stupio je na snagu tek 2010. Kako se ovim Protokolom mijenja nadzorni sustav nad primjenom Konvencije, bilo je potrebno da ga ratificiraju sve države ugovornice, no Rusija je uporno to odbijala učiniti. Tek nakon donošenja Protokola 14bis (kojemu je cilj bio provođenja promjena iz Protokola 14. neovisno o ratifikaciji svih država članica) Rusija je ratificirala Protokol 14. te je on stupio na snagu.

6 Konferencija na visokoj razini: „Implementacija Europske konvencije o ljudskim pravima, naša zajednička odgovornost”, Deklaracija iz Bruxellesa, 27. ožujka 2015., prijevod Deklaracije i popratnog Akcijskog plana dostupni su na https:/uredzastupnika.gov.hr/UserDocsImages/dokumenti/ KLJU\%C4\%8CNI\%20DOKUMENTI/Briselska\%20Deklaracija\%20(final).pdf.

European Court of Human Rights, Country profiles, Croatia, www.echr.coe.int/Documents/CP Croatia_ENG.pdf.

8 Sam Sud ovlašten je donositi deklaratorne presude, uz iznimku primjerice u predmetu Gluhaković protiv Hrvatske (zahtjev br. 21188/09, od 12. IV. 2011.) kada je Sud naložio RH koje mjere mora poduzeti za izvršenje presude: „Presuđuje da će tužena država osigurati djelotvoran kontakt između podnositelja zahtjeva i njegove kćerke u vrijeme koje je spojivo s radnim rasporedom podnositelja zahtjeva $i \mathrm{u}$ prikladnim prostorijama..." 


\section{TUMAČENJE KONVENCIJE}

Postoji nekoliko pristupa pitanju tumačenja Konvencije (Schabas, 2017.; Merrills, 1990.; Mowbray, 2005.; Linderfalk, 2010.; Bates, 2010.; Mahoney, 1990.; Omejec, 2013.; Popović, 2011.), dok je za pravno filozofsko razumijevanje istih svakako vrijedno spomenuti autore Letsasa (Letsas, 2007.; 2009.) i Dzehtsiraoua (Dzehtsiraou, 2011.; 2015.). U ovom radu bit će prikazana načela tumačenja relevantna za razumijevanje pristupa Sudu prilikom donošenja presuda protiv RH prikazanih u radu a koja su: načelo autonomnog tumačenja pojmova, načelo evolutivnog tumačenja, načelo učinkovitosti, te načelo slobodne procjene, dok, prema autorici, sva ova načela možemo izvesti iz ključnog načela, načela teleološkog tumačenja. ${ }^{9}$

\section{1. (TELEOLOŠKO) TUMAČENJE KONVENCIJE PREMA BEČKOJ KONVENCIJI O PRAVU MEĐUNARODNIH UGOVORA}

Kod tumačenja međunarodnih ugovora, kao što je Konvencija, načelo teleološkog tumačenja oslanja se na pravila za tumačenje ugovora koja postavlja Bečka konvencija o pravu međunarodnih ugovora (1969. ${ }^{10}$ (dalje u tekstu: BK), i to prvenstveno na čl. 31. navedene Konvencije koji predstavlja Opće pravilo o tumačenju. ${ }^{11}$ Sam je Sud počeo s pozivanjem na odredbe BK čak i prije nego je ista stupila na snagu, i to u predmetu Golder protiv $U K^{12}$ gdje je naglasio kako BK kodificira postojeća pravila međunarodnog prava. Unatoč ovako eksplicitnom pozivanju na BK u presudi iz 1975., nakon ove presude Sud se gotovo nikad nije pozvao izravno na BK, tek u rijetkim presudama u kojima je tumačio Konvenciju

9 Prema Viskoviću, ciljno, odnosno teleološko tumačenje jest glavni način razumijevanja pravnih normi, a isto pruža dva odgovora na pitanje što je ciljno tumačenje. Prvi jest kako bi ciljno tumačenje trebalo tražiti ono što su normotvorci htjeli postići normama (subjektivno ciljno tumačenje), dok je drugi kako bi ciljno tumačenje trebalo tražiti one ciljeve koje društvo postavlja u vrijeme primjene norme, neovisno o tome što su tom normom htjeli postići normotvorci (objektivno ciljno tumačenje) (Visković, 2006., str. 249-253).

10 Bečka konvencija o pravu međunarodnih ugovora, NN MU 16/1993.

11 1. Ugovor se mora tumačiti u dobroj vjeri, prema uobičajenom smislu izraza iz ugovora u njihovu kontekstu i u svjetlu predmeta i svrhe ugovora.

2. U svrhu tumačenja ugovora, osim teksta, uključujući preambulu i priloge, kontekst obuhvaća: (a) svaki sporazum koji se odnosi na ugovor, a kojeg su sve stranke sklopile u vezi s ugovorom; (b) svaku ispravu koju jedna ili više stranaka sastave u vezi s ugovorom, a koju ostale stranke prihvate kao ispravu koja se odnosi na ugovor.

3. Zajedno s kontekstom, vodit će se računa: (a) o svakom naknadnom sporazumu između stranaka o tumačenju ugovora ili o primjeni njegovih odredba; (b) o svakoj naknadnoj praksi u primjeni ugovora kojom se ustanovljuje sporazum između stranaka o tumačenju ugovora; (c) o svakom mjerodavnom pravilu međunarodnog prava primjenjivom na odnose između stranaka.

4. Poseban smisao pridaje se nekom izrazu ako je ustanovljeno da je to bila namjera stranaka.

12 Zahtjev br. 4451/70, od 21.2.1975, § 29. 
na ograničavajući način, odnosno pozivajući se na dopunske metode tumačenja iz čl. 32. koje uključuju pripremne radove i okolnosti pod kojima je ugovor sklopljen. ${ }^{13}$

Ključno pravilo tumačenja iz BK sadržano je u čl. 31. st. 1. koji se odnosi na tumačenje u dobroj vjeri, prema uobičajenom smislu izraza iz ugovora u njihovu kontekstu i u svjetlu predmeta i svrhe ugovora, no taj stavak ne može se promatrati izdvojeno od ostalih stavaka. Konkretno, st. 2. možemo promatrati kao „unutarnji kontekst“, st. 3. kao „vanjski kontekst“, dok je st. 4. usmjeren na namjeru stranaka (Schabas, 2017., str. 36). Razvitak načela tumačenja ključnih za postojeću praksu Suda prije svega proizlazi iz tumačenja u skladu sa čl. 31. st. 3. i to podstavaka b) i c) koji se odnose na naknadnu praksu stranaka u primjeni ugovora kojom se ustanovljuje sporazum o tumačenju ugovora, te na mjerodavna pravila međunarodnog prava primjenjiva na odnose između stranaka (iako, kao što je već naglašeno, sam se Sud u svojoj praksi gotovo nikada ne referira izravno na BK). Upravo je pozivanjem na naknadnu praksu stranaka sukladno čl. 31. st. 3.b) došlo do tumačenja Konvencije kao živućeg instrumenta koji treba tumačiti u skladu s aktualnim zahtjevima društva, o čemu će biti više govora u nastavku. Čl. 31. st. 3.c) referira se na mjerodavna pravila međunarodnog prava primjenjiva na odnose između stranaka i ovakvo tumačenje Sud vrlo često primjenjuje, pozivajući se na tzv. europski konsenzus (ili nedostatak istog), ${ }^{14}$ zajedničke vrijednosti, ${ }^{15}$ ili prihvaćena pravila međunarodnog prava, odnosno međunarodne ugovore, ${ }^{16}$ pa čak ponekad i ako nisu ratificirani od države u odnosu na koju Sud donosi presudu. ${ }^{17}$

Zaključno, a s obzirom da se Sud nije izravno pozivao na BK i metode tumačenja koje iz nje proizlaze, osim iznimno, tijekom svog rada razvio je vlastite metode tumačenja (iako vidimo da se sve one mogu podvesti pod pravila tumačenja sadržana u BK). Iz navedenog razloga, ključne će metode tumačenja biti prikazane na način na koji ih je Sud koristio bez izravnog pozivanja na BK, i to kao: načelo autonomnog tumačenja, načelo evolutivnog tumačenja, načelo učinkovitosti i načelo slobodne procjene država.

13 Čl. 32. BK o dopunskim sredstvima tumačenja. Vidi presudu Magyar Helsinki Bizottság v Hungary, zahtjev br. 18030/11, [VV ] od 8. XI. 2016; odluku Banković i drugi protiv Belgije $i$ drugih, zahtjev br. 52207/99 [VV] od 12. XII. 2001.; te presudu Johnston i drugi protiv Irske, zahtjev br. 9697/82, od 18. XII. 1986. Za detaljnije vidi Marochini, 2014., str. 63.- 84.i Letsas, 2010.

14 S. H. i dr. protiv Austrije, zahtjev br. 57813/00, od 3. XI. 2011.

15 Primjerice prihvaćanje kako manjine uživaju posebnu zaštitu, odnosno kako su prepoznate njihove specijalne potrebe za zaštitom, gdje je Sud naglasio Rome kao manjinu kojoj je takva zaštita potrebna, koje se očituje i u presudi Velikog vijeća u predmetu Oršuš protiv Hrvatske, zahtjev br. 15766/03, [VV] od 16. III. 2010. o kojoj će biti govora u nastavku.

16 Poput Konvencije o pravima djeteta, NN MU, 12/93; Haške konvencije o građanskopravnim aspektima međunarodne otmice djece (Konvencija je objavljena u S1. 1. bivše SFRJ MU 7/1991. Notifikacijom o sukcesiji Hrvatska je postala strankom Konvencije 8. listopada 1991. (NN MU, br. 4/1994); te Europske socijalne povelje (Zakon o potvrđivanju Europske socijalne povelje, Dodatnog protokola Europskoj socijalnoj povelji, Protokola o izmjenama Europske socijalne povelje i Dodatnog protokola Europskoj socijalnoj povelji, NN 15/2002).

17 Vidi presudu Ž. B. protiv Hrvatske, zahtjev br. 47666/13, od 11. VII. 2017. gdje se Sud pozvao na Istanbulsku konvenciju koju RH još nije ratificirala, kao i vrlo značajnu presudu Marckx protiv Belgije, zahtjev br. 6833/74, od 13. VI. 1979. gdje se Sud pozvao na dvije Konvencije koje Belgija nije ratificirala (jednu je potpisala dok drugu nije niti potpisala). 


\subsection{AUTONOMNO TUMAČENJE KONVENCIJE}

Vrlo rano u praksi Suda pojavilo se pitanje kako tumačiti pojmove iz Konvencije. Sud je na ovo pitanje odgovorio već u presudi Engel protiv Nizozemske iz 1976. uvođenjem koncepta autonomnog tumačenja pojmova. Autonomni koncept predstavlja specifično načelo tumačenja usko povezano s tumačenjem Konvencije u skladu s njegovom ciljem i svrhom, a znači da će u određenim situacijama Sud dati autonomno značenje pojmovima iz Konvencije, bez obzira na njihovo značenje na nacionalnoj razini te će procjenjivati de facto situacije u svakom pojedinom predmetu. Naime, načelo autonomnosti ima zadaću osigurati jedinstvenu primjenu konvencijskih pravnih pojmova unutar nacionalnih pravnih sustava, ali i sačuvati njihovo izvorno konvencijsko značenje sprečavajući njihovu promjenu jednostranim djelovanjem nacionalnih vlasti. ${ }^{18}$ Iz navedenih razloga, Sud nacionalne definicije koristi samo kao „polazišnu točku“ za tumačenje pojmova (Human Rights Education for Legal Professionals, 2009., str. 5). Autonomno tumačenje pojmova danas se vrlo često koristi i to za definiranje niza konvencijskih pojmova. ${ }^{19}$

\subsection{EVOLUTIVNO TUMAČENJE/ NAČELO ŽIVUĆEG INSTRUMENTA}

Načelo živućeg instrumenta, odnosno evolutivno tumačenje pojmova ,,jedno je od najpoznatijih načela sudske prakse u Strasbourgu. Ono predstavlja izraz načela da se Konvencija treba tumačiti ,u svjetlu današnjih uvjeta i da se razvija kroz tumačenje Suda." (Wildhaber, 2004., str. 84). Evolutivno tumačenje proizlazi prije svega iz karaktera Konvencije kao ugovora kojim se štite ljudska prava. Početkom primjene Konvencije na ovakav pristup se povremeno gledalo s dozom otpora, pa čak i kao na nedopušteni sudački aktivizam, te je bio i ostao predmet brojnih kritika. ${ }^{20}$ Jedan od najvećih problema prilikom primjene ovog načela tumačenja jest nepredvidivost sudaca, koji ponekad primjenjuju načelo evolutivnog tumačenja nedovoljno (ili uopće ne), obrazlažući razloge za primjenu istog, ${ }^{21}$ a koji kao problem postoji od samih početaka primjene ovog načela.

18 Svrha je autonomnog tumačenja Konvencije spriječiti da se konvencijska prava „... podrede tumačenju koje pojam ili načelo imaju u domaćem pravu država ugovornica”. Letsas, 2007., str. 48.

19 Tako Sud autonomno tumači građanska prava i obveze; pojam kaznene optužnice; doma; dopisivanja; obiteljskog života; privatnog života; vlasništva kao i brojne druge pojmove. Treba spomenuti kako je Sud s primjenom autonomnog tumačenja išao toliko daleko da je nekim pravima, poput odredbe Konvencije koja jamči pravo na udruživanje (čl. 11.) dao značenje suprotno namjeri stvaratelja Konvencije, što je zapravo neprihvatljivo sa stajališta tumačenja jer se ulazi u polje stvaranje prava. Young, James $i$ Webster protiv UK, zahtjev br. 8793/79, od 21. II. 1986.

20 Sudac Fitzmaurice najpoznatiji je po svojoj kritici evolutivnom tumačenju Konvenciji, $i$ to $u$ dvije ključne presude za ovakvo tumačenje, Golder protv UK i Tyrer protiv UK, zahtjev br. 5856/72, od 25. IV. 1978. U presudi Tyrer je prvi put Sud opisao Konvenciju kao živući instrument no učinio je to bez detaljnog ulaženja u razloge za donošenje takve odluke. Vidi također Scoppola protiv Italije (br. 2), zahtjev br. 10249/03, [VV] od 17. IX. 2009.

21 Ovaj problem pojavio se već u prvoj presudi, Tyrer protiv UK. Iako, za detaljniju analizu evolutivnog tumačenja vidi Letsas, 2010., str.527.-532 i Dzehtsiarou, 2014. 
Unatoč navedenim kritikama i problemima, evolutivno tumačenje Konvencije zapravo je najprihvaćenija i najčešće korištena metoda tumačenja, a primjenu iste vidjet ćemo u brojnim presudama protiv RH. Također, zajedno s autonomnim tumačenjem pojmova, omogućuje sucima da Konvenciju kao „,stari instrument“ prilagode današnjim uvjetima i promjenama u društvenoj zbilji. ${ }^{22}$

\subsection{NAČELO UČINKOVITOSTI}

Načelo učinkovitosti kao načelo tumačenja proizlazi iz potrebe da prava iz Konvencije uživaju „djelotvornu i učinkovitu“ zaštitu, a ne zaštitu koja je „teoretska i iluzorna“. Samim time, kako bi se pružila takva zaštita pravima, državama se nameću brojne pozitivne obveze. Srž načela učinkovitosti jest kako države ne mogu postupati u skladu s Konvencijom jednostavno zabranom ponašanja koja je u suprotnosti s Konvencijom, već moraju poduzeti pozitivne radnje kako bi zaštitile prava pojedinaca. Prva presuda u kojoj je načelo učinkovitosti korišteno bila je Golder protiv $U K$, i već je ovdje upotreba ovog načela bila kontroverzna. Iako u početku kontroverzno, tumačenje u skladu s ovim načelom danas je općeprihvaćeno, što ćemo vidjeti i u hrvatskim predmetima.

\subsection{NAČELO POLJA SLOBODNE PROCJENE DRŽAVA}

U praksi Europskog suda, polje slobodne procjene razvijeno je da bi se državama, odnosno nacionalnim vlastima, omogućio manevarski prostor u granicama u kojima im je Sud spreman isti dati, a da one ispunjavaju svoje obveze prema Konvenciji (Greer, 2000., str. 5) i budući da je bilo potrebno razviti metodu tumačenja „kako bi se razgraničilo između onoga što je na zajednici da odlučuje na lokalnoj razini i onoga što je toliko temeljno da podrazumijeva iste zahtjeve svim državama bez obzira na varijacije tradicije i kulture" (Mahoney, 1998., str. 1). Polje slobodne procjene nije propisano Konvencijom ${ }^{23}$ već je razvijeno od strane strazburških tijela kako bi se naglasila supsidijarna uloga Suda u zaštiti temeljnih prava, odnosno kako bi se državi dopustila određena mjera diskrecije u ograničenju konvencijskih prava. Međutim, širina dopuštene granice procjene varira u stupnjevima diskrecije ovisno o kontekstu no ne može se donijeti jasan zaključak o tome kada će Sud dopustiti široku slobodu procjene, a kada će istu suziti. Nepostojanje jasnih kriterija primjene predstavlja veliki problem u primjeni i tumačenju Konvencije, stvarajući pravnu nesigurnost kod potencijalnih podnositelja i država ugovornica. Unatoč problemima,

22 Kao primjer primjene načela živućeg instrumenta možemo uzeti zabranu primjene smrtne kazne prema praksi Suda, iako čl. 2. Konvencije dopušta primjenu smrtne kazne u izvršenju sudske presude. Sud je svoje stajalište o općoj zabrani smrtne kazne obrazložio pozivanjem na činjenicu da je Europa danas teritorij bez smrtne kazne. Vidi npr. Al-Saadoon i Mufdhi protuv UK, zahtjev br. 61498/08, od 2. III. 2010.

23 Iako, kada (odnosno ako) Protokol 15. stupi na snagu, Preambuli Konvencije na kraju će se dodati nova odredba koja će naglasiti načelo supsidijarnosti i sloboda procjene koju uživaju države ugovornice. 
Sud polje slobodne procjene primjenjuje prilikom odlučivanja o brojnim pitanjima, pa tako i u hrvatskim predmetima koji će biti prikazani u nastavku.

\section{PRIMJENA I TUMAČENJE KONVENCIJE U REPUBLICI HRVATSKOJ}

Nakon jednog zahtjeva iz 1998., daljnji (dopušteni) zahtjevi protiv Republike Hrvatske podneseni su 1999. o kojima je Sud donio presude 2001. godine, a odnosili su se na članak 6. Konvencije i pravo na pošteno suđenje, pravo u odnosu na koje je do danas doneseno najveći broj presuda. ${ }^{24}$

Prva presuda koja je uslijedila u 2002. bila je od velikog praktičnog značaja te predstavlja, prema mišljenju autorice, trenutak kada se šira hrvatska, kako pravna tako i javnost općenito, upoznala s radom Europskog suda. Naime, radilo se o predmetu Mikulić protiv Hrvatske, ${ }^{25}$ gdje je Sud utvrdio povredu prava podnositeljice na privatni život zbog neučinkovitosti domaćih sudova u postupku u kojem se tražilo utvrđenje očinstva. Prema stavu Suda, neučinkovitost i dugotrajnost postupka (preko 4 godine za postupak utvrđivanja očinstva) prouzročili su kod podnositeljice produljenu nesigurnost u pogledu njezina porijekla. Posljedično, Sud nije našao samo povredu čl. 8. već i povredu prava na suđenje u razumnom roku.

Ovaj predmet ima značaj zbog utvrđenja pozitivne obveze Hrvatske da osigura učinkovit pravni sustav - sustav koji će djetetu omogućiti da u sporu utvrđivanja očinstva utvrdi identitet svoga oca u razumnom roku, upravo primjenjujući načelo učinkovitosti te zahtijevajući djelotvornu zaštitu konvencijskih prava. Također, slijedom izvršenja iste, donesen je novi Obiteljski zakon (2003. godine) prema kojemu je rok za izvođenje dokaza u postupku utvrđivanja očinstva bio 3 mjeseca (od dana dostave rješenja strankama), te ako se u navedenom roku tuženi nije odazvao pozivima, Sud je bio ovlašten donijeti presudu neovisno o neprovođenju vještačenja. ${ }^{26}$

Presude koje su uslijedile (iz 2003.) ponovno su se odnosile na povredu prava na pošteno suđenje i to suđenja u razumnom roku i prava na pristup sudu, kao i čl. 13. a odnosi se na pravo na djelotvoran pravni lijek. Međutim, već 2004. godine donesena je presuda kojom je utvrđena povreda prava na poštovanje doma, Cvijetić protiv Hrvatske, ${ }^{27}$ a problem istaknut u presudi proteže se do danas. Nakon ovoga, uslijedili su brojni zahtjevi u kojima su se podnositelji pozivali na povredu prava

24 Truhli protiv Hrvatske; Horvat protiv Hrvatske, zahtjev br. 51585/99, od 26. VII. 2001.; Cerin protiv Hrvatske, zahtjev br. 4727/00, od 15. XI. 2001.; Futterer protiv Hrvatske, zahtjev br. 52634/99, od 20. XII. 2001. U radu presude protiv RH koje se odnose na čl. 6. Konvencije, posebice njegov građanski aspekt, neće biti analizirane, s obzirom na njihovu brojnost, a i s obzirom na to da iste ne predstavljaju aktualne izazove u primjeni i tumačenju Konvencije. Međutim, za detaljni prikaz i analizu navedenih presuda vidi Grbić, 2014.

25 Mikulić protiv Hrvatske, zahtjev br. 53176/99, od 4. XI. 2002.

26 Obiteljski zakon, NN 116/2003, čl. 292.

27 Cvijetić protiv Hrvatske, zahtjev br. 71549/01, od 26. II. 2004. 
na dom od strane RH, koji će biti prikazani u nastavku zajedno s presudama Suda i postupkom izvršenja. Međutim, prije prikaza spomenutih presuda i ostalih aktualnih izazova, treba spomenuti i dvije kontroverzne odluke Velikog vijeća, Blečić i Orššs.

\subsection{UKRATKO O DVJEMA KONTROVERZNIM ODLUKAMA VELIKOG VIJEĆA}

U predmetu Blečić protiv Hrvatske ${ }^{28}$ zahtjev podnositeljice odnosio se na povredu poštovanja prava na dom zbog gubitka stanarskog prava nad stanom u kojem je živjela. Vijeće Suda je utvrdilo kako nije došlo do povrede prava podnositeljice, smatrajući da je odluka nacionalnih tijela bila donesena uz uvažavanje načela razmjernosti. Međutim, predmet je upućen Velikom vijeću koje je u svojoj odluci proglasilo nenadležnosti ratione temporis smatrajući kako je domaća presuda postala res judicata 15. veljače 1996. godine kada je Vrhovni sud svojom presudom preinačio presudu Županijskoga suda, unatoč naknadnoj odluci Ustavnog suda (iz studenog 1999.) o nedopuštenosti tužbe. Slijedom navedenog, miješanje pada izvan vremenske nadležnosti Suda, s obzirom da je u RH Konvencija stupila na snagu u studenom 1997.

Ova odluka naišla je na brojne kritike, kako domaćih i inozemnih pravnika, tako i samih sudaca koji su bili u sastavu Velikog vijeća (odluka je donesena s 11 sudaca za i 6 protiv ovakve odluke). Do dana današnjeg ostaje nejasan ratio Suda u ovom predmetu, s obzirom na to da je jedan od uvjeta dopuštenosti za podnošenja zahtjeva Sudu iscrpljivanje domaćih pravnih lijekova, što svakako za zahtjeve iz Republike Hrvatske uključuje i podnošenje ustavne tužbe, koja, ako se „preskoči“ kao pravni lijek, predstavlja prepreku za podnošenje zahtjeva Europskom sudu.

Slijedom ove odluke, nametnulo se pitanje koji je sud u Republici Hrvatskoj kompetentniji za odlučivanje o pitanjima povrede temeljnih ljudskih prava od Ustavnog suda? Nadalje, uvidom u presude i odluke Europskog suda, jasno je kako se u svim odlukama u kojima postoji konačna odluka Ustavnog suda (a to je većina odluka, osim u nekim specifičnim predmetima gdje su se, zbog okolnosti i hitnosti u postupanju, podnositelji obratili Sudu prije iscrpljivanja domaćih pr. sredstava), šestomjesečni rok računa upravo od dana zaprimanja odluke Ustavnog suda. ${ }^{29}$ Konačno, što bi bilo da je Ustavni sud prihvatio tužbu podnositeljice i preinačio odluku Vrhovnog suda? Koji datum bi u tom slučaju kao relevantan uzeo Europski sud? U navedenom predmetu kao problem se postavila i mogućnost da se predmet Blečić počne koristiti kao presedan u budućim predmetima. No, 11 godina nakon odluke Velikog vijeća možemo reći da do toga (srećom) nije došlo.

Sljedeća kontroverzna odluka jest Oršuš i drugi protiv Hrvatske gdje je Veliko vijeće, za razliku od Vijeća, suzilo polje slobodne procjene Hrvatske u području obrazovanja romske djece i našao povredu prava podnositelja na obrazovanje (čl. 1.

28 Zahtjev br. 59532/00, [VV] odluka od 8. III. 2006.

29 Vidi Pavlović i drugi protiv Hrvatske, zahtjev br. 13274/11, od 2. IV. 2015., § 32. 
Pr. 2) zajedno sa zabranom neizravne diskriminacije (čl. 14.). Ovdje valja istaknuti stajalište manjine od 8 sudaca iz sastava Velikog vijeća koji su smatrali da je većina procjenjivala ovaj predmet kao sredstvo za daljnji razvoj koncepta indirektne diskriminacije u praksi Europskog suda. Kao rezultat takvog pristupa, ova je presuda postala presuda o položaju Roma općenito, a ne presuda utemeljena na činjenicama predmeta. Također su naglasili da u situaciji kada je Europski sud preinačio dobro obrazloženu presudu Ustavnog suda Republike Hrvatske (U-III-3138/2002 od 7. veljače 2007.) koja se temeljila na konvencijskim principima, kao i jednoglasno usvojenu presudu Vijeća tog istoga Suda, da je tijesna većina trebala uvjerljivije argumentirati svoju odluku, te ponuditi praktične smjernice o tome kako dalje razvijati i primjenjivati koncept indirektne diskriminacije.

\subsection{AKTUALNI IZAZOVI U PRIMJENI I TUMAČENJU KONVENCIJE}

\subsubsection{Pitanja povrede prava na dom i prava na mirno uživanje vlasništva}

Kao primjeri primjene autonomnog tumačenja uz sužavanje polja slobodne procjene državi

Zahtjeve i presude protiv Republike Hrvatske koji se tiču povrede prava na poštovanje doma možemo podijeliti u dvije skupine:

1) Predmeti u kojima su državna tijela provođenjem pozitivnih domaćih propisa dovela podnositelje zahtjeva u stanje u kojem gube svoje domove, a ti propisi se, upravo zbog posljedica koje imaju na uživanje doma, preispituju pred Europskim sudom. Upravo su ovi predmeti izvor najvećih ,problema“ u hrvatskom sustavu, jer nacionalni sudovi do nedavno nisu bili skloni korištenju nužnog testa razmjernosti već isključivo primjenjivati pozitivne propise i ispitivati ima li podnositelj pravnu osnovu živjeti u navedenom domu. Ključni predmeti protiv Republike Hrvatske u ovom pitanju jesu Ćosić, Orlić; Paulić, Bjedov, Brežec i Tijardović. ${ }^{30}$

2) Predmeti gdje su podnositeljima zahtjeva drugi subjekti neovlašteno upali i boravili u stanu iz kojeg razloga podnositelji nisu mogli živjeti u svom stanu (podnositelji nisu bili vlasnici, već je vlasnik bila RH, a podnositelji su imali posjed), unatoč presudama domaćih sudovima. Dakle, ključni je problem u navedenim predmetima neučinkovitost u radu državnih tijela, neispunjenje pozitivnih obveza neprovođenjem ovrha na temelju pravomoćnih i ovršnih domaćih sudskih odluka ishođenih radi zaštite posjeda zbog oduzimanja. Za ovu skupinu je ključan gore spomenuti predmet $C$ vijetić, te predmeti Pibernik $i$ Kunić, ${ }^{31}$ u kojima je

30 Ćosić protiv Hrvatske, zahtjev br. 28261/06, od 15. I. 2009.; Orlić protiv Hrvatske, zahtjev br. 48833/07, od 21. VI. 2011.; Paulić protiv Hrvatske, zahtjev br. 3572/06, od 22. X. 2009.; Bjedov protiv Hrvatske, zahtjev br. 42150/09, od 29. V. 2012.; Brežec protiv Hrvatske, zahtjev br. 7177/10, od 18. VII. 2013.; Tijardović protiv Hrvatske, zahtjev br. 38906/13, presuda od 19. VI. 2014.

31 Pibernik protiv Hrvatske, zahtjev br. 75139/01, od 4. III. 2004.; Kunić protiv Hrvatske, zahtjev br. 22344/02, od 11. I. 2007. 
podnositeljima utvrđena povreda prava na dom kao i prava na suđenje u razumnom roku. ${ }^{32}$

Za Republiku Hrvatsku, predmeti iz prve skupine svakako predstavljaju veliki izazov. U spomenutim predmetima Sud, primjenjujući načela razmjernosti i autonomnog tumačenja, stavlja vlasnike u nepovoljniji položaj u odnosu na osobe koje bez pravne osnove borave u domu. Također, za izvršenje ovih presuda, osim pojedinačnih mjera je (bilo) potrebno poduzeti i brojne opće mjere, koje se kreću od zakonodavnih promjena, do promjena u praksi hrvatskih sudova, od najnižih do Ustavnog suda te držim kako su ove presude zaista dovele do značajnih promjena u praksi hrvatskih sudova koji su i sami počeli primjenjivati navedeni test, kao i do zakonodavnih promjena.

Prije svega valja spomenuti kako Sud autonomno tumači pojam doma, ne uzimajući u obzir nacionalne definicije. Kao rezultat takvog tumačenja činjenica postojanja doma u kontekstu čl. 8. ovisi o činjeničnim pretpostavkama, odnosno o postojanju dostatne i trajne veze pojedinca s prostorom, a ne o postojanju pravne osnove. Takvo poimanje doma hrvatsko pravo ne poznaje (Mihelčić, Marochini, 2014., str. 168-169). Nadalje, Sud zahtijeva od nacionalnih tijela primjenu testa razmjernosti prilikom odlučivanja o tome treba li podnositelja iseliti iz doma ili ne. Bez ulaženja u pojedinosti navedenih predmeta (Ćosić, Orlić, Paulić, Bjedov, Brežec i Tijardović), ono što im je svima zajedničko jest kako su podnositelji u trenutku podnošenja zahtjeva Sudu boravili u stanovima bez pravne osnove, da su postojale odluke nacionalnih sudova o njihovu iseljenju (koje još nisu izvršene) te da je Sud utvrdio povredu prava na poštovanje doma, upravo primjenjujući načelo autonomnosti i test razmjernosti. Primjerice, u predmetu Tijardović, podnositeljica je živjela u stanu u Splitu nad kojim nikada nije stekla zaštićenog najmoprimca ili bilo koje drugo pravo na taj stan (već je nad tim stanom stanarsko pravo imao njen svekar), te su domaći sudovi našli kako nema pravne osnove za stanovanje u stanu naloživši njeno iseljenje. Suprotno tome, Europski je sud smatrao kako je pred domaćim tijelima podnositeljica iznijela tvrdnje koje su zahtijevale od domaćih sudova ispitivanje razmjernosti, odnosno nužnosti njenog iseljenja koji su, propustivši to učiniti, povrijedili pravo podnositeljice na poštovanje doma. ${ }^{33}$

Glede općih mjera nužnih za izvršenje navedenih presuda, Odbor ministara trenutno razmatra zakonska rješenja iz pročišćenog teksta Ovršnog zakona ${ }^{34}$ te ostaje za vidjeti hoće li ista pružiti rješenje problema koji se proteže pred Sudom od 2006. godine. Još 2011. je RH poslala Odboru ministara Akcijsko izvješće u kojemu se pozvala i na promjenu prakse Ustavnog suda, no kako Odbor ministara

32 Za detaljnije vidi: Mihelčić, Marochini, 2014.

33 Zanimljivo, Sud je također primijetio da izdavanje naloga za iseljenje nije zatraženo sve do 2007. godine (u kontekstu postupka u kojem je podnositeljica zahtjeva tražila da se prizna njezino pravo na otkup stana kao nositeljice stanarskog prava) odnosno da vlasnik stana nije od početka imao čvrsto stajalište glede prava podnositeljice da prebiva u stanu.

34 Ovršni zakon, pročišćeni tekst zakona, NN 112/12, 25/13, 93/14, 55/16, 73/17. 
još uvijek nije zaključio nadzor nad izvršenjem presuda, očito je da su daljnje mjere (bile) i još uvijek su potrebne. ${ }^{35}$

S druge strane, treba spomenuti predmete u kojima su podnositelji tvrdili povredu prava na mirno uživanje vlasništva, zbog pogodnosti koje uživaju zaštićeni najmoprimci. Sud je u ovim predmetima utvrdio sistemski i repetitivni problem koji se pojavljuje na strani vlasnika stanova i nametnuo obvezu Republici Hrvatskoj što hitnijeg rješenja navedenog problema. Ključni je predmet u ovom polju Sergej Statileo protiv Hrvatske ${ }^{36}$ iz 2014. godine nakon kojeg su uslijedila još tri slična zahtjeva u kojima je Sud našao povredu prava na mirno uživanje vlasništva, Bego $i$ dr., Mirošević-Anzulović i Gošović. ${ }^{37}$ Za očekivati je, ukoliko se ovaj problem ubrzo ne riješi donošenjem i provođenjem zadovoljavajućeg zakonskog okvira, da će biti još sličnih predmeta pred Sudom.

Kao primjer navest ćemo predmet Statileo gdje je podnositelj zahtjeva (vlasnik stana, najmodavac) odbio sklopiti ugovor o najmu i ugovoriti zaštićenu najamninu zahtjeva, pa je najmoprimac tužbom tražio donošenje presude koja bi zamijenila takav ugovor, i uspio u tome. ${ }^{38}$ Europski sud, odlučujući o povredi prava na mirno uživanje vlasništva podnositelja, odnosno, ispitujući opravdanost/razmjernost miješanja, utvrdio je da uvjet razmjernosti nije zadovoljen. Naglasio je kako sustav zaštićenog najma nema odgovarajuća procesna jamstva u cilju postizanja ravnoteže između interesa zaštićenih najmoprimaca i onih najmodavaca. Nadalje, iako u područjima kao što je stanovanje države nužno imaju široku slobodu procjene, ova sloboda procjene nije neograničena i njezina provedba, čak i u kontekstu najsloženije reforme države, ne može dovesti do posljedica koje su protivne standardima Konvencije. Zaključno, Sud nije pronašao zahtjeve općeg interesa koji bi mogli opravdati tako sveobuhvatna ograničenja podnositeljevih vlasničkih prava te je našao kako je na podnositelja zahtjeva kao najmodavca stavljen nerazmjeran i pretjerani pojedinačni teret, $s$ obzirom na to da je morao snositi većinu socijalnih $\mathrm{i}$ financijskih troškova stambenog zbrinjavanja zaštićenog najmoprimca. ${ }^{39}$

Vezano uz problem izvršenja ove i kasnijih presuda po istoj osnovi, Odbor ministara je naglasio kako ovaj problem može biti riješen samo donošenjem odgovarajućih zakonskih rješenja (a ne pojedinačnim mjerama) te kako je hrvatska vlada obećala donijeti potrebne izmjene do kraja 2015. godine, no kako do istih nije došlo. Ono što su vlasti učinile jest izdavanje javnog poziva vlasnicima stanova u kojima žive zaštićeni najmoprimci, radi upisa/registracije u Ministarstvo graditeljstva i prostornog uređenja, te je nakon provođenja upisa ustanovljeno kako

\footnotetext{
35 Action report DH-DD(2011)327, http://hudoc.exec.coe.int/eng\#\{“"EXECIdentifier”:[“DHDD(2011)327E"]\}.

36 Sergej Statileo protiv Hrvatske, zahtjev br. 12027/10, od 10. VII. 2014.

37 Bego i dr. protiv Hrvatske, zahtjevi br. 35444/12, 35576/12, 41555/12, 41558/12 i 48914/12, od 15.11.2016.;
}

Mirošević-Anzulović protiv Hrvatske, zahtjev br. 25815/14, od 4. X. 2016.; Gošović protiv Hrvatske, zahtjev br. 37006/13, od 4. IV. 2017.

38 Za detaljniju analizu predmeta Statileo vidi Mihelčić, Marochini Zrinski, 2017., str. 955-983.

39 Sergej Statileo protiv Hrvatske, §§123.-145. 
u RH postoji 3734 stanova u privatnom vlasništvu u kojima živi otprilike 9000 stanara. Na svom 1265. sastanku u rujnu 2016. Odbor ministara je pozvao hrvatske vlasti da im proslijede prijedlog zakona kako bi mogli ispitati njegovu usklađenost sa zaključcima Suda. Kako hrvatske vlasti još nisu dale nikakav odgovor Odboru ministara, čini se da je izvršenje navedenih presuda još daleko od zaključenja.

\subsubsection{Aktualni problemi vezani uz kaznene postupke kao primjeri primjene} načela učinkovitosti. Kada govorimo o presudama u predmetima vezanima uz kaznene postupke vođene u RH, svakako treba spomenuti presudu u predmetu Dvorski ${ }^{40}$ donesenu od Velikog vijeća gdje je isto utvrdilo kako je cijeli postupak bio nepošten za podnositelja iz razloga što mu je uskraćeno pravo na branitelja po vlastitom izboru zajamčeno čl. 6. st. 3.c). Konkretno, podnositelj, nakon uhićenja i zadržavanja, nije obaviješten o dolasku branitelja kojeg su izabrali njegovi roditelji, iako je isti više puta dolazio u policijsku postaju, a i sam podnositelj je tražio da se njega pozove, već mu je omogućeno da odabere odvjetnika s popisa odvjetnika Riječke odvjetničke komore, što je u konačnici i učinio. Podnositelj zahtjeva je potom, u prisutstvu tako izabranog odvjetnika, potpisao zapisnik o svojoj izjavi u kojoj je priznao pljačku, trostruko ubojstvo i palež te je osuđen od strane Županijskog suda u Rijeci na maksimalnu kaznu zatvora u trajanju od 40 godina.

Veliko vijeće je, imajući u vidu da je priznanje podnositelja pred policijom bilo jedan od ključnih dokaza na suđenju koje je uslijedilo, utvrdilo kako je takav nedostatak u zastupanju utjecao na cijeli postupak, čineći ga nepoštenim, protivno čl. 6.1. Ovakvu odluku je Veliko vijeće donijelo, između ostalog, pozivajući se na načelo učinkovitosti, naglasivši „kako bi pravo na pošteno suđenje ostalo ,praktično i učinkovito", članak 6. stavak 1. zahtijeva da, u pravilu, pristup odvjetniku treba osigurati od prvog policijskog ispitivanja osumnjičenika..." ${ }^{\text {"41 }}$ U konkretnom je predmetu Veliko vijeće otišlo korak dalje u obvezama države, s obzirom na to da je podnositelj imao branitelja tijekom cijelog postupka, no isti nije izabran temeljem informiranog odabira. Ova presuda će svakako imati brojne posljedice, kako za samog podnositelja, tako i za tijela uključena u kaznene progone u RH. Treba naglasiti kako je predmet trenutno pred Vrhovnim sudom na odlučivanju o obnovi postupka, a koju je odbio Županijski sud. ${ }^{42}$

40 Dvorski protiv Hrvatske, zahtjev br. 25703/11, [VV] od 20. X. 2015.

${ }_{41}$ Ibid., § 80. Iako, ovaj se predmet odnosi na situaciju gdje je podnositelju zahtjeva omogućen pristup odvjetniku od njegova prvog ispitivanja, no ne odvjetniku prema vlastitom izboru. Za razliku od predmeta koji uključuju uskraćivanje pristupa, u situacijama iz kojih proistječe manje ozbiljno pitanje „uskraćivanja izbora” primjenjuje se blaži zahtjev „mjerodavnih i dovoljnih” razloga. Međutim, i ovdje se Sud poziva na namjenu Konvencije zajamčiti prava koja su praktična i učinkovita, a ne teoretska $\mathrm{i}$ iluzorna.

42 Ostaje za vidjeti što će biti s obnovom postupka podnositelja zahtjeva, pogotovo u slučaju da do iste dođe, uzimajući u obzir navode suca Zupančiča u njegovu izdvojenom mišljenju o nužnosti ekskluzije svih dokaza do kojih je došlo bez prisutnosti odvjetnika po izboru podnositelja (među ostalim i njegova priznanja), a koji su bili ključni za donošenje presude protiv podnositelja. Dvorski v Croatia, status izvršenja presude, http://hudoc.exec.coe.int/eng\#\{\%22fulltext $\% 22:[\% 22$ dvorski $\% 22], \% 22$ EXECDocum entTypeCollection\%22:[\%22CEC\%22],\%22EXECIdentifier\%22:[\%22004-10141\%22]\}. 
Glede daljnih predmeta koji se odnose na nedostatke u kaznenim postupcima valja spomenuti najaktualniji problem koji se odnosi na nezakonitost i neopravdanost tajnih mjera nadzora, odnosno prisluškivanja i snimanja telefonskih razgovora, te korištenja tako dobivenih podataka kao dokaza u postupcima protiv podnositelja zahtjeva. Isto pitanje se pojavilo u predmetima Bašić, Dragojević i Matanović ${ }^{43}$ gdje su se podnositelji pozvali na povrede čl. 8. zbog nezakonitih tajnih mjera nadzora i čl. 6. zbog uporabe nezakonitih dokaza u kaznenom postupku, odnosno njihova utjecaja na pravičnost postupka u cjelini. Sud je, u svim predmetima našao povredu čl. 8., a glede utjecaja tako dobivenih dokaza na poštenost postupka naglasio da su pravila o dopuštenosti dokaza prvenstveno stvar koju reguliraju nacionalni zakoni, ne nalazeći povredu i dopuštajući državama široko polje slobodne procjene u reguliranju pitanja nezakonitih dokaza. Ovdje nećemo ulaziti u problematiku primjene nezakonito prikupljenih dokaza i njihovu dokaznu snagu u kaznenim postupcima, ${ }^{44}$ već samo onu u vezanu uz članak 8 . i nužnost obrazloženja mjera tajnog nadzora.

Naime, u sva tri predmeta Sud je našao kako rješenja istražnih sudaca, kojima je USKOK-u dozvoljeno snimanje i nadziranje telefonskih razgovora podnositelja zahtjeva, nisu bila dovoljno obrazložena, štoviše, uopće nisu sadržavala obrazloženje zbog čega se ista svrha (prikupljanje dokaza) ne bi mogla ostvariti nekom blažom mjerom, iako to zahtijeva Zakon o kaznenom postupku. Također, Sud je primijetio i da sudska praksa hrvatskih sudova dopušta mogućnost i da dozvola za nadzor i tehničko snimanje telefonskih razgovora uopće ne bude obrazložena, što otvara široku mogućnost zlouporabe te tajne mjere. Sud je smatrao da mjerodavno domaće pravo, na način na koji su ga tumačili i primijenili nadležni sudovi, nije bilo razumno jasno u pogledu opsega i načina ostvarivanja diskrecije dodijeljene tijelima javne vlasti, te posebice u praksi nije osiguralo odgovarajuće mjere zaštite od raznih mogućih zloupotreba. Time je, zaključio je Europski sud, povrijeđeno pravo podnositelja na poštovanje njihova privatnog života i korespondencije. ${ }^{45}$ Iako ovi predmeti nisu problematični s aspekta tumačenja Konvencije, svakako su problematični za RH, zbog tumačenja zakona od strane nacionalnih sudova i ostalih odgovornih tijela, a kojima se povređuje Konvencija.

Odbor ministara je u postupku nadzora nad izvršenjem ovih presuda naveo kako mjere podizanja svijesti te objavljivanja i širenja informacija nisu dostatne već je potrebno primijeniti i druge mjere, posebno s obzirom na činjenicu da su trenutno pred Europskim sudom još najmanje 4 predmeta koji čekaju na odlučivanje a vezani su uz slično činjenično stanje. ${ }^{46}$ Ipak, navedene presude imale su izravan utjecaj

43 Dragojević protiv Hrvatske, zahtjev br. 68955/11, od 15. IV. 2015.; Bašić protiv Hrvatske, zahtjev br. 22251/13, od 25. X. 2016.; Matanović protiv Hrvatske, zahtjev br. 2742/12, od 4. IV. 2017.

44 Za detaljnije o navedenoj temi vidi Martinović, Kos, 2016.

45 Vlada Republike Hrvatske, Ured zastupnika za ljudska prava, https://uredzastupnika.gov.hr/ vijesti/nova-presuda-dragojevic-protiv-hrvatske/230.

46 Dragojević v Croatia, status izvršenja presude, http://hudoc.exec.coe.int/eng\#\{\%22EXECIdentifi er\%22:[\%22004-12061\%22]\}. 23. studenog 2017. Sud je donio još jednu presudu, Grba protiv Hrvatske (47074/12) u kojoj je našao povredu čl. 6. i 8. Konvencije. 
na odlučivanje Vrhovnog suda koji je u svojom rješenju od 5. rujna 2017. I KžUs 116/2017-4 revidirao svoj prethodni stav zahtijevajući da nalog za provođenje posebnih dokaznih radnji kojim se privremeno ograničavaju određena ustavna prava i sloboda u svome obrazloženju ne bude manjkav (i time rezultira povredom čl. 8).

Zaključno, a s obzirom na aktualnost rasprave o ratifikaciji u Republici Hrvatskoj (u listopadu i studenom 2017.) Istanbulske konvencije o borbi protiv nasilja i sprečavanja nasilja nad ženama i u obitelji, treba spomenuti presudu Suda iz srpnja 2017., Ž. B. protiv Hrvatske gdje je Sud, neovisno o činjenici da navedena Konvencija još nije ratificirana u RH, na nekoliko mjesta u presudi naglasio kako je zakonodavni okvir koji RH pruža žrtvama obiteljskog nasilja u skladu sa zahtjevima iz Istanbulske konvencije. ${ }^{47}$ Standarde iz Istanbulske konvencije Sud, kako sam naglašava, već koristi kao međunarodno priznate i prihvaćene, iako je do listopada 2017. samo 18 država članica Vijeća Europe ratificiralo spomenutu Konvenciju. No, čini se kako će se, kroz praksu Suda, s primjenom Istanbulske konvencije započeti i prije njene ratifikacije, pa čak i neovisno o činjenici ratifikacije. ${ }^{48}$

Svakako ne smijemo zanemariti i druge presude koje se odnose na problem nasilja nad ženama, odnosno obiteljskog nasilja, gdje je Sud utvrdio povredu Konvencije u predmetima Tomašić Branko $i$ dr. $i$ Bljakaj $i$ dr. ${ }^{49}$ u oba utvrdivši povredu postupovnog aspekta čl. 2. zbog nezadovoljavajućeg i neučinkovitog djelovanja nadležnih tijela u zaštiti života.

4.2.3. Loši uvjeti u zatvorima koji rezultiraju povredom čl. 3. konvencije kao primjeri primjene evolutivnog tumačenja. Sljedeća važna skupina predmeta pred Europskim sudom koja se odnosi na Republiku Hrvatsku jesu predmeti u kojima se pojavljuje pitanje povrede čl. 3. (zabrana mučenja, nečovječnog i ponižavajućeg postupanja i kažnjavanja) zbog loših uvjeta u zatvorima, odnosno svim ustanovama u kojima se nalaze osobe lišene slobode. Iako je i sam Sud rekao kako uvjeti u zatvorima u Republici Hrvatskoj ne predstavljaju strukturni problem, činjenica jest da je u svim predmetima u kojima je Sud odlučivao o povredi čl. 3. zbog loših uvjeta u zatvorima ista utvrđena ${ }^{50}$ (osim u predmetu Pozaić). ${ }^{51}$

Samo pitanje uvjeta u zatvorima Sud uopće nije razmatrao kao aspekt čl. 3. do $2001 .^{52}$ kada je prvi put našao kako loši uvjeti u zatvorima sami po sebi mogu

$47 \check{Z}$. B. protiv Hrvatske, $\S 37 .-38$., te 56.

48 Isto je Sud učinio u jednoj od prvih presuda u kojima je utvrdio pozitivne obveze država, Marckx protiv Belgije, također se pozivajući na Konvencije koje Belgija još nije ratificirala, no primjenjujući načelo živućeg instrumenta i razvoj standarda u zaštiti ljudskih prava na teritoriju država članica Vijeća Europe.

49 Tomašić Branko i dr. protiv Hrvatske, zahtjev br. br. 46598/06, od 15. I. 2009.; Bljakaj i dr. protiv Hrvatske, zahtjev br. 74448/12, od 18. IX. 2014.

50 Vidi predmete Cenbaur protiv Hrvatske, zahtjev br. 73786/01, od 9. III. 2006., Štitić protiv Hrvatske, zahtjev br. 29660/03, od 8. XI. 2007., Testa protiv Hrvatske, zahtjev br. 20877/04, od 12. VII. 2007., Pilčić protiv Hrvatske, zahtjev br. 33138/06, od 17. I. 2008., Dolenec protiv Hrvatske, zahtjev br. 25282/06, od 26. XI. 2009., Longin protiv Hrvatske, zahtjev br. 49268/10, od 6. XI. 2012., te Lonić protiv Hrvatske, zahtjev br. 8067/12, od 4. XII. 2014.

51 Pozaić protiv Hrvatske, zahtjev br. 5901/13, od 4. XII. 2014.

52 Dougoz protiv Grčke, zahtjev br. 40907/98, od 6. III. 2001. 
predstavljati povredu čl. 3., što je zaključio tumačeći Konvenciju evolutivno, kao živući instrument. Do tada se uvjetima u zatvorima bavio isključivo Europski odbor za sprečavanje mučenja, nečovječnog i ponižavajućeg postupanja ili kažnjavanja (CPT). Ne ulazeći ovdje u problematiku pitanja zašto se Europski sud počeo baviti uvjetima u zatvorima, ${ }^{53}$ osvrnut ćemo se samo na konkretne probleme koji se javljaju prilikom izvršenja ovih presuda u Republici Hrvatskoj, kao i na najnoviju presudu donesenu od Velikog vijeća u predmetu Muršić protiv Hrvatske. ${ }^{54}$ U navedenoj presudi je Veliko vijeće, suprotno zaključcima Vijeća, presudilo kako je došlo do povrede čl. 3. i to iz razloga što je podnositelj u razdoblju od uzastopnih 27 dana raspolagao sa 2,62 $\mathrm{m} 2$ osobnog prostora što predstavlja izrazito ozbiljan nedostatak osobnog prostora. Za ostalo razdoblje i ostale navode podnositelja je Veliko vijeće utvrdilo kako nema povrede čl. 3. Kod ovog predmeta, kao i kod svih predmeta u kojima je Sud utvrdio povredu čl. 3. zbog nezadovoljavajućih uvjeta u zatvorima, ispunjenje pojedinačnih mjera nužnih za izvršenje presuda nije problematično, jer se sastoji od isplaćivanja pravične naknade i eventualnog premještaja u „Zadovoljavajuće uvjete“" ${ }^{55}$ već je problem izvršenje općih mjera.

Naime, niti prva presuda donesena zbog nezadovoljavajućih uvjeta u zatvorima (Cenbaur iz 2006.) još nije u potpunosti izvršena što samo za sebe govori o kompleksnosti i problematici ispunjenja općih mjera kod ovakvih presuda koje su financijski i vremenski zahtjevne. Iako su hrvatske vlasti poduzele niz mjera za poboljšanje uvjeta u zatvorima, o čemu su obavijestile Odbor ministara koji ih je prihvatio kao dio nužnih općih mjera, isti je u svom zadnjem izvješću naglasio nužnost poduzimanja daljnjih mjera za poboljšanje uvjeta u zatvorima, od povećanja i restrukturiranja prostora u kojima borave zatvorenici, do kvalitetnije medicinske skrbi.

\subsubsection{Aktualna obiteljskopravna problematika kao primjeri primjene} autonomnog i evolutivnog tumačenja. Sljedeću skupinu predmeta koju svakako valja spomenuti čine predmeti obiteljskopravne pozadine, u kojima je Europski sud našao niz nedostataka, kako u radu nadležnih tijela (prvenstveno sudova i centara za socijalnu skrb), tako i u samom zakonodavstvu.

Prva presuda iz oblasti obiteljskog prava jest već spomenuta presuda Mikulić protiv Hrvatske, dok od ostalih valja izdvojiti presude Adžić, Karadžić i Vujica ${ }^{56}$ kao skupinu predmeta u kojima su nacionalna tijela svojim neučinkovitim djelovanjem povrijedila odredbe Haške konvencije o građanskopravnim aspektima međunarodne otmice djece, a time i čl. 8. Konvencije. Svakako su značajne i presude Gluhaković,

53 Za detaljnije vidi Marochini, 2013., str. 77-106.

54 Muršić protiv Hrvatske, zahtjev br. 7334/13, [VV] od 20. X. 2016.

55 Kod većine presuda, zatvorenici su odslužili zatvorske kazne te više ne borave u zatvoru stoga su isplate pravičnih naknada bile dovoljne za izvršenje pojedinačnih mjera. Vidi Cenbaur v Croatia, status izvršenja presude, http://hudoc.exec.coe.int/eng\#\{\%22EXECIdentifier\%22:[\%22004-10073\%22]\}.

56 Adžić protiv Hrvatske, zahtjev br. 22643/14, od 12. III. 2015.; Karadžić protiv Hrvatske, zahtjev br. 35030/04, od 15. XII. 2005.; te Vujica protiv Hrvatske, zahtjev br. 56163/12, od 8. X. 2015. 
Krušković i Ribic $c^{57}$ gdje su podnositelji zahtjeva bili očevi i gdje je Sud našao povredu prava zajamčenih čl. 8., zbog sporosti, pretjeranog formalizma i neučinkovitog rada nadležnih domaćih tijela, odnosno neispunjenja pozitivnih obveza države kojima se omogućuje praktično i učinkovito uživanje konvencijskog prava na poštovanje obiteljskog života.

Od navedenih presuda, valjda izdvojiti onu u predmetu Krušković jer je izravno utjecala na promjene u Obiteljskom zakonu. Naime, podnositelju je povrijeđeno pravo na poštovanje obiteljskog života koje, prema mišljenju Suda, obuhvaća i potencijalne očeve (autonomno tumačenje pojma obiteljski život), kako zbog neučinkovitog rada nacionalnih tijela (prvenstveno Centra za socijalnu skrb), tako i zbog nepostojanja zakonskog rješenja kojim bi se omogućilo priznanje očinstva i osobama koje su lišene poslovne sposobnosti. ${ }^{58}$

Iz navedenih razloga, u noveli Obiteljskog zakona koji je trenutno na snazi u čl. 63. stoji da očinstvo može priznati punoljetna osoba neovisno o svojoj poslovnoj sposobnosti dok čl. 64. traži, za upis priznanja očinstva, pristanak punoljetne majke neovisno o njezinoj poslovnoj sposobnosti. ${ }^{59}$

\subsubsection{Presude u kojima je utvrđena diskriminacija podnositelja kao primjeri} primjene autonomnog i evolutivnog tumačenja. Četiri su ključne presude protiv Republike Hrvatske koje treba izdvojiti u domeni zabrane diskriminacije. Prvo, predmet Oršuš sažeto prikazan supra, zatim predmet $\breve{S} e c ̌ i c^{60}$ koji se odnosi na nedostatak istrage o rasnim motivima napada, što je prvi predmet u kojem je Sud utvrdio pozitivnu proceduralnu obvezu u okviru čl. 3. istražiti sve navode o rasno motiviranom napadu. Nadalje, treba spomenuti presudu Topić-Rosenberg ${ }^{61} \mathrm{zbog}$ nejednakog postupanja hrvatskih vlasti prema posvojiteljima u odnosu na biološke roditelje u pogledu prava na roditeljski dopust, te konačno presudu Pajić protiv Hrvatske $^{62}$ o kojoj će biti riječi u nastavku.

Presuda Pajić protiv Hrvatske iz 2016. ima značaj iz razloga što je Sud utvrdio kako istospolna zajednica spada u koncept kako ,privatnog života, tako i obiteljskog života" s obzirom na autonomnost pojmova i evolutivnu narav njihova tumačenja, neovisno o nacionalnom shvaćanju, te kako je došlo do diskriminacije na osnovi seksualne orijentacije podnositeljice s obzirom na to da se prema Zakonu o strancima

57 Gluhaković protiv Hrvatske; Krušković protiv Hrvatske, zahtjev br. 46185/08, od 21. VI. 2011.; te Ribić protiv Hrvatske, zahtjev br. 27148/12, od 2. IV. 2015.

58 Gosp. Kruškoviću je 2003. oduzeta poslovna sposobnost zbog dugotrajne ovisnosti o drogi i organskoga poremećaja osobnosti kao i antisocijalnog poremećaja osobnosti.

59 Zanimljivo je ovdje spomenuti obrazloženje prijedloga Obiteljskog zakona iz 2015. jer se predmet Krušković spominje na više mjesta, a posebice kod članka 63. gdje stoji: „Povod predloženim izmjenama glede priznanja očinstva od strane maloljetnih osoba (djece) i punoljetnih osoba koje nisu poslovno sposobne su višestruki: 1. Presuda Europskoga suda za ljudska prava u predmetu Krušković protiv Hrvatske..." (Prijedlog obiteljskog zakona (2015.), Nacrt Vlade Republike Hrvatske, https://vlada. gov.hr/UserDocsImages/Sjednice/2015/.../231\%20-\%201.pdf, str. 194.-195.).

60 Šečić protiv Hrvatske, zahtjev br. 40116/02, od 31. V. 2007.

${ }^{61}$ Topić-Rosenberg protiv Hrvatske, zahtjev br. 19391/11, od 14. XI. 2013.

62 Pajić protiv Hrvatske, zahtjev br. 68453/13, od 23. II. 2016. 
osobe u izvanbračnoj zajednici smatraju članovima uže obitelji dok su osobe u istospolnoj zajednici potpuno isključene iz Zakona.

Postupak izvršenja ove presude je u studenom 2017. još uvijek na razmatranju od Odbora ministara ${ }^{63}$ no kako su donesene i stupile na snagu izmjene Zakona o strancima (srpanj 2017.), za pretpostaviti je kako će Odbor ministara prihvatiti hrvatsko izvješće. Naime, članku 56. Zakona o strancima iz 2011. koji je bio sporan, odnosno diskriminatoran, dodan je podstavak b. kojim se regulira privremeni boravak istospolnih parova u svrhu životnog partnerstva. ${ }^{64} \mathrm{U}$ svom izvješću je Republika Hrvatska navela i mjere koje poduzima u svrhu podizanja svijesti, poput diseminacije navedene presude hrvatskim sudovima. Ostaje za vidjeti hoće li doista navedene legislative i praktične mjere biti dostatne za sprečavanje možebitnih budućih diskriminacija u navedenom polju.

\section{ZAKLJUČAK}

Ovaj rad ne predstavlja pokušaj detaljne analize presuda protiv Republike Hrvatske donesene od strane Europskog suda, niti prikaz svih presuda, već onih koje su, prema mišljenju autorice, na neki način oblikovale stav kako šire javnosti tako i specijaliziranije (pravne) struke o radu Europskog suda. Ne ulazeći u dubinu svih navedenih presuda ili pitanja, vidljivi su veliki pomaci i promjene u stajalištima i pristupu hrvatskih tijela zaduženih za primjenu i provedbu Konvencije i presuda Europskog suda.

Iako je najveći broj presuda protiv Republike Hrvatske donesen zbog povrede prava na pošteno suđenje, u ovom radu iste nisu analizirane jer one ne predstavljaju izazov za primjenu i tumačenje Konvencije u RH. Stoga su u radu prikazane, osim dvije kontroverzne odluke Velikog vijeća, aktualne presude koje predstavljaju izazov u primjeni i tumačenju Konvencije u Republici Hrvatskoj. Glavnina opisanih presuda Europskog suda vodi se načelima razmjernosti, učinkovitosti, širokog i autonomnog tumačenja konvencijskih pojmova i zajamčenih prava, načelima koje hrvatski pravni pozitivisti nisu (bili) skloni primjenjivati.

U predgovoru svoje knjige o Konvencijskom acquisu Jasna Omejec napisala je: ,(...)Na školovanje mnogih generacija pravnika u Hrvatskoj nije utjecao ni razvitak europskih pravnih standarda što su ih u svoje pravne sustave postupno ugrađivale europske države koje su već od kraja 50-ih godina prošlog stoljeća bile podvrgnute jurisdikciji Europskog suda. Ukratko, tumačenje i primjena prava u našoj zemlji bili su, a u velikoj su mjeri i danas, opterećeni krutim „tekstualnim“ ili „gramatičkim“ pozitivizmom koji priječi da se konkretni slučajevi sagledavaju kontekstualno i teleološki. Konvencija, međutim, traži promjenu. Ona traži odmak

${ }^{63}$ Pajic $v \quad$ Croatia, status izvršenja presude, http://hudoc.exec.coe.int/ eng\#\{\%22fulltext $\% 22:[\% 22$ pajic $\% 20 v \% 20$ croatia $\% 22], \% 22$ EXECDocumentTypeCollection $\% 22:[\% 22$ $\mathrm{CEC} \% 22]\}$.

64 Zakon o strancima, NN 130/11, 74/13, 69/17. 
od takve vrste pozitivizma i prihvaćanje većeg broja različitih, za nas novih, načela interpretacije prava, kao i prihvaćanje osobite, za nas nove, metodologije obrade konkretnih slučajeva. Riječ je o zahtjevima koji traže radikalnu promjenu pravne svijesti odnosno promjenu pravnog razmišljanja. Iskustvo govori da puka navođenja pravnih stajališta Europskog suda, a da ih se ne razjasni kontekstualno i podrobnije ne prikaže, jednostavno nisu dovoljna“ (Omejec, 2013., str. X). S ovim stajalištem Omejec se slažem te bih samo dodala kako se problem na koji upućuje neće riješiti samo revidiranjem pravnog pozitivističkog stava hrvatskih pravnika nego i jačanjem društvene uloge sudaca u hrvatskom društvu.

\section{POPIS LITERATURE}

\section{KNJIGE}

Bates, E. (2010.), The Evolution of the European Convention on Human Rights: From Its Inception to the Creation of a Permanent Court of Human Rights, OUP, Oxford, 2010.

Dzehtsiarou, K., (2015.) European consensus and the legitimacy of the European court of human rights. CUP, Cambridge.

Grbić, S. (2014.), Pošteno suđenje u građanskim postupcima u Hrvatskoj u svjetlu članka 6., stavka 1. Europske konvencije o ljudskim pravima, Pravni fakultet Sveučilišta u Rijeci, Rijeka.

Greer, S. (2005.), The Margin of Appreciation: Interpretation and Discretion under the European Convention on Human Rights, Human Rights files No. 17, CoE Publishing, Strasbourg.

Greer, S. (2006.), The European Convention on Human Rights, Achievements, Problems and Prospects, CUP, Cambridge.

Linderfalk, U. (2010.), On the Interpretation of Treaties, The Modern International Law as Expressed in the 1969 Vienna Convention on the Law of Treaties, Springer Netherlands, 2010.

Letsas, G. (2007.), A Theory of Interpretation of the European Convention on Human Rights, OUP, Oxford.

Marochini, M. (2013.), Socio-economic dimension of the ECHR, Pravni fakultet u Rijeci, Rijeka.

Merrills, J.G. (1990.), The development of international law by the European Court of Human Rights, MUP, Manchester.

Omejec, J. (2013.), Konvencija za zaštitu ljudskih prava i temeljnih sloboda u praksi Europskog suda za ljudska prava, Strasburški acquis, Novi informator, Zagreb.

Popović, D. (2011.), The Emergence of the European Human Rights Law, An Essay on Judicial Creativity, Eleven International Publishing, Utrecht.

Schabas, W. A. (2017.), The European Convention on Human Rights, A Commentary, OUP, Oxford. 
Visković, N. (2006.), Teorija prava i države, Birotehnika, Zagreb.

\section{ČLANCI}

Dzehtsiarou, K. (2011.). „European Consensus and the Evolutive Interpretation of the European Convention on Human Rights“. German Law Journal, 12, 1730-1745.

Letsas, G. (2010.), „Strasbourg's interpretative ethic: lessons for the international lawyer“, The European Journal of International Law, Vol. 21 no. 3, 509.-541.

Mahoney, P. (1990.), ,Judicial activism and judicial self-restraint in the European Court of Human Rights: two sides of the same coin“, 11 Hum. Rts. L. J. 57.

Mahoney, P. (1998.), „The Doctrine of the Margin of Appreciation under the European Convention on Human Rights: Its Legitimacy in Theory and Application in Practice“, 19(1) Hum. Rts. L. J. 1.

Marochini, M. (2014.), ,The interpretation of the European Convention Human Rights“, Zbornik radova Pravnog fakulteta u Splitu, god. 51, br. 1, str. 63- 84.

Martinović, I., Kos, D. (2016.), ,Nezakoniti dokazi: Teorijske i praktične dvojbe u svjetlu prakse Europskog suda za ljudska prava“. Hrvatski ljetopis za kazneno pravo i praksu, 23(2), str. 311-338.

Mihelčić, G., Marochini, M. (2014.), „Koneksitet ostvarenja vindikacijskog zahtjeva na nekretnini i tzv. prava na poštovanje doma“, Zbornik PFR, (1991.) v. 35, br. 1. str. 163-192.

Mihelčić, G., Marochini, M. (2014.), „Reforma ovrhe na nekretnini u hrvatskom pravu u svjetlu konvencijskog prava“, Zbornik radova Aktualnosti građanskog $i$ trgovačkog zakonodavstva i pravne prakse, br. 12, Mostar, 2014., str. 200-213.

Mihelčić, G., Marochini Zrinski, M. (2017.), Utjecaj zaštite konvencijskih prava na ugovor o najmu stana, XIII. Majsko savjetovanje: Uslužno pravo, Pravni fakultet Kragujevac, Srbija, str. 955.-983.

Mowbray, A. (2005.), „The Creativity of the European Court of Human Rights“, 5 Hum. Rts. L. Rev. 57.

Wildhaber, L. (2004.), „,The European Court of Human Rights in Action“, 21 Ritsumeikan Law Review 83.

\section{INTERNETSKI IZVORI}

Action report DH-DD(2011)327, http://hudoc.exec.coe.int/ eng\#\{“EXECIdentifier”:[“DH-DD(2011)327E”]\}

Cenbaur v Croatia, status izvršenja presude, http://hudoc.exec.coe.int/eng\#\{\%22EXEC Identifier\%22:[\%22004-10073\%22]\}.

Dragojević v Croatia, status izvršenja presude, http://hudoc.exec.coe.int/eng\#\{\%22EX ECIdentifier\%22:[\%22004-12061\%22]\} 
Dvorski v Croatia, status izvršenja presude, http://hudoc.exec.coe.int/eng\#\{\%22fulltext \%22:[\%22dvorski\%22],\%22EXECDocumentTypeCollection\%22:[\%22CEC\%22],\%22EX ECIdentifier\%22:[\%22004-10141\%22]\}

European Court of Human Rights, Country profiles, Croatia, www.echr.coe.int/ Documents/CP_Croatia_ENG.pdf

Human Rights Education for Legal Professionals, Key concepts of the European Convention on Human Rights, (CoE September 2009), https://rm.coe.int/16805ab706

Konferencija na visokoj razini: „Implementacija Europske konvencije o ljudskim pravima, naša zajednička odgovornost”, Deklaracija iz Bruxellesa, 27. ožujka 2015., prijevod Deklaracije i popratnog Akcijskog plana su dostupni na: https://uredzastupnika. gov.hr/UserDocsImages/dokumenti/KLJU\%C4\%8CNI\%20DOKUMENTI/Briselska\%20 Deklaracija\%20(final).pdf

Pajic $v$ Croatia, status izvršenja presude, http://hudoc.exec.coe.int/ eng\#\{\%22fulltext $\% 22:[\% 22$ pajic $\% 20 v \% 20$ croatia\%22],\%22EXECDocumentTypeCollect ion\%22:[\%22CEC\%22]\}

Praktični vodič kroz uvjete dopuštenosti, Vijeće Europe/Europski sud za ljudska prava, 2011. (Sudska praksa - Analiza sudske prakse - Vodič o dopuštenosti), www.echr.coe.int

Prijedlog obiteljskog zakona (2015.), Nacrt Vlade Republike Hrvatske, https://vlada. gov.hr/UserDocsImages/Sjednice/2015/.../231\%20-\%201.pdf,

Vlada Republike Hrvatske, Ured zastupnika za ljudska prava, https://uredzastupnika. gov.hr/vijesti/nova-presuda-dragojevic-protiv-hrvatske/230

\section{PRAVNI IZVORI}

Bečka konvencija o pravu međunarodnih ugovora, NN MU 16/1993.

Europska socijalna povelja (Zakon o potvrđivanju Europske socijalne povelje, Dodatnog protokola Europskoj socijalnoj povelji, Protokola o izmjenama Europske socijalne povelje i Dodatnog protokola Europskoj socijalnoj povelji, NN 15/2002.

Haška konvencija o građanskopravnim aspektima međunarodne otmice djece (Konvencija je objavljena u Sl. l. bivše SFRJ MU 7/1991). Notifikacijom o sukcesiji Hrvatska je postala strankom Konvencije 8. listopada 1991. (NN MU, br. 4/1994).

Konvencija o pravima djeteta, NN MU, 12/93.

(Europska) Konvencija za zaštitu ljudskih prava i temeljnih sloboda, pročišćeni tekst, MU 18/97, 6/99, 14/02, 13/03, 9/05, 1/06, 2/10.

Obiteljski zakon, NN 116/2003.

Ovršni zakon, pročišćeni tekst zakona, NN 112/12, 25/13, 93/14, 55/16, 73/17.

Zakon o strancima, NN 130/11, 74/13, 69/17. 


\section{SUDSKA PRAKSA EUROPSKOG SUDA ZA LJUDSKA PRAVA}

Adžić protiv Hrvatske, zahtjev br. 22643/14, od 12. III. 2015.

Al-Saadoon i Mufdhi protuv UK, zahtjev br. 61498/08, od 2. III. 2010. 2001

Banković i drugi protiv Belgije i drugih, zahtjev br. 52207/99 [VV] odluka od 12. XII.

Bašić protiv Hrvatske, zahtjev br. 22251/13, od 25. X. 2016.

Bego i dr. protiv Hrvatske, zahtjevi br. 35444/12, 35576/12, 41555/12, 41558/12 i 48914/12, od 15. XI. 2016.

Bjedov protiv Hrvatske, zahtjev br. 42150/09, od 29. V. 2012.

Blečić protiv Hrvatske, zahtjev br. 59532/00, [VV] odluka od 8. III. 2006.

Bljakaj i dr. protiv Hrvatske, zahtjev br. 74448/12, od 18. IX. 2014.

Brežec protiv Hrvatske, zahtjev br. 7177/10, od 18. VII. 2013.

Cenbaur protiv Hrvatske, zahtjev br. 73786/01, od 09. III. 2006.

Cerin protiv Hrvatske, zahtjev br. 4727/00, od 15. XI. 2001.

Cvijetić protiv Hrvatske, zahtjev br. 71549/01, od 26. II. 2004.

Ćosić protiv Hrvatske, zahtjev br. 28261/06, od 15. I. 2009.

Dolenec protiv Hrvatske, zahtjev br. 25282/06, od 26. XI. 2009.

Dougoz protiv Grčke, zahtjev br. 40907/98, od 6. III. 2001.

Dragojević protiv Hrvatske, zahtjev br. 68955/11, od 15. IV. 2015.

Dvorski protiv Hrvatske, zahtjev br. 25703/11, [VV] od 20. X. 2015.

Futterer protiv Hrvatske, zahtjev br. 52634/99, od 20. XII. 2001.

Gluhaković protiv Hrvatske, zahtjev br. 21188/09, od 12. IV. 2011.

Golder protiv Ujedinjenog Kraljevstva, zahtjev br. 4451/70, od 21. II. 1975.

Gošović protiv Hrvatske, zahtjev br. 37006/13, od 4. IV. 2017.

Horvat protiv Hrvatske, zahtjev br. 51585/99, od 26. VII. 2001.

Johnston i drugi protiv Irske, zahtjev br. 9697/82, od 18. XII. 1986.

Karadžić protiv Hrvatske, zahtjev br. 35030/04, od 15. XII. 2005.

Krušković protiv Hrvatske, zahtjev br. 46185/08, od 21. VI. 2011.

Kunić protiv Hrvatske, zahtjev br. 22344/02, od 11. I. 2007.

Longin protiv Hrvatske, zahtjev br. 49268/10, od 06. XI. 2012.

Lonić protiv Hrvatske, zahtjev br. 8067/12, od 4. XII. 2014.

Magyar Helsinki Bizottság v Hungary, zahtjev br. 18030/11, [VV ] od 8. XI. 2016.

Marckx protiv Belgije, zahtjev br. 6833/74, od 13. VI. 1979.

Matanović protiv Hrvatske, zahtjev br. 2742/12, od 4. IV. 2017.

Mikulić protiv Hrvatske, zahtjev br. 53176/99, od 4. XI. 2002.

Mirošević-Anzulović protiv Hrvatske, zahtjev br. 25815/14, od 4. X. 2016. 
Muršić protiv Hrvatske, zahtjev br. 7334/13, [VV] od 20. X. 2016.

Orlić protiv Hrvatske, zahtjev br. 48833/07, od 21. VI. 2011.

Oršuš protiv Hrvatske, zahtjev br. 15766/03, [VV] od 16. III. 2010.

Pajić protiv Hrvatske, zahtjev br. 68453/13, od 23. II. 2016.

Paulić protiv Hrvatske, zahtjev br. 3572/06, od 22. X. 2009.

Pavlović i drugi protiv Hrvatske, zahtjev br. 13274/11, od 2. IV. 2015.

Pibernik protiv Hrvatske, zahtjev br. 75139/01, od 4. III. 2004.

Pilčić protiv Hrvatske, zahtjev br. 33138/06, od 17. I. 2008.

Pozaić protiv Hrvatske, zahtjev br. 5901/13, od 4. XII. 2014.

Ribić protiv Hrvatske, zahtjev br. 27148/12, od 2. IV. 2015.

Scoppola protiv Italije (br. 2), zahtjev br. 10249/03, [VV] od 17. IX. 2009.

Sergej Statileo protiv Hrvatske, zahtjev br. 12027/10, od 10. VII. 2014.

S.H. i dr. protiv Austrije, zahtjev br. 57813/00, od 3. XI. 2011.

Šečić protiv Hrvatske, zahtjev br. 40116/02, od 31. V. 2007.

Štitić protiv Hrvatske, zahtjev br. 29660/03, od 8. XI. 2007.

Testa protiv Hrvatske, zahtjev br. 20877/04, od 12. VII. 2007.

Tijardović protiv Hrvatske, zahtjev br. 38906/13, presuda od 19. VI. 2014.

Tomašić Branko i dr. protiv Hrvatske, zahtjev br. br. 46598/06, od 15. I. 2009.

Topić-Rosenberg protiv Hrvatske, zahtjev br. 19391/11, od 14. XI. 2013.

Truhli protiv Hrvatske, zahtjev br. 45424/99, od 28. VI. 2001.

Tyrer protiv UK, zahtjev br. 5856/72, od 25. IV. 1978.

Vujica protiv Hrvatske, zahtjev br. 56163/12, od 8. X. 2015.

Young, James $i$ Webster protiv UK, zahtjev br. 8793/79, od 21. II. 1986.

Ž.B. protiv Hrvatske, zahtjev br. 47666/13, od 11. VII. 2017.

\section{CHALLENGES IN THE APPLICATION AND INTERPRETATION OF THE CONVENTION IN THE REPUBLIC OF CROATIA}

The European Convention for the Protection of Human Rights and Fundamental Freedoms, as the most important pan-European human rights treaty and the European Court of Human Rights as a body responsible for monitoring the implementation of the Convention, are of great importance to Croatia. This paper will outline the judgments and decisions of the Court against Croatia, which, in the opinion of the author, are significant for the Croatian legal order, some because they have led to legislative changes, some because they were the driving force for changes in the behaviour of the competent Croatian bodies. In addition, some decisions will be presented because they provoked controversies among the Croatian public primarily because of the way the Court applies and interprets the Convention. For the latter reason, the paper also presents the methods of interpretation 
Dr. sc. Maša Marochini Zrinski: Izazovi u primjeni i tumačenju Konvencije u Republici Hrvatskoj Zbornik radova Pravnog fakulteta u Splitu, god. 55, 2/2018., str. 423.- 446.

used by the Court, since the practice of the European Court and the way in which the Court interprets the Convention differ largely from the positivist application of rights characteristic for Croatia.

Key words: European Convention for the Protection of Human Rights and Fundamental Freedoms; European Court of Human Rights; interpretation of the Convention; decisions and judgments of the Court concerning Croatia 